\title{
Élelmiszer-igazságosság, avagy hogyan lehet igazságos az élelmiszerrendszer a termelőtől a fogyasztó asztaláig?'
}

\section{Food justice: How is it possible Farm-to- table?}

\author{
Neulinger Ágnes² - Birtalan llona Liliána ${ }^{3}$ \\ https://doi.org/10.51624/SzocSzemle.2021.2.4 \\ Beérkezés: 2021. 03. 24. \\ Átdolgozott változat beérkezése: 2021. 08. 02. \\ Elfogadás: 2021. 08. 30.
}

\begin{abstract}
Összefoglaló: Az élelmiszerrendszer működése és jellemzői számos kérdést felvetnek az igazságosság szempontjából, köszönhetően elsősorban a nagyüzemi gazdálkodásnak, a foglalkoztatási sajátosságoknak és a kapcsolódó egészségügyi következményeknek. Az élelmiszer-igazságosság ideája az élelmiszerellátási lánc teljességét érinti az ún. „termelőtől a fogyasztó asztaláig” megközelítés keretében. A kérdéskör iránt élénk érdeklődés indult a 2000-es években, ezzel együtt magyar nyelvű publikáció elvétve található a témában. Jelen tanulmány célja, hogy bemutassa az élelmiszer-igazságosság ideáját és mozgalmát, kitérve azokra az aktuális kihívásokra, amelyek a 21. század mezőgazdaságát érintik az igazságosság tekintetében. A tanulmányban áttekintjük az élelmiszer-igazságosságot termelői és fogyasztói nézőpontból, valamint bemutatjuk az alternatív élelmiszerrendszereket, amelyek megoldást kínálhatnak az élelmiszer-termeléshez és fogyasztáshoz kapcsolódó igazságtalanságok megszüntetésére.
\end{abstract}

Kulcsszavak: élelmiszer-igazságosság, fogyasztó, termelő, helyi gazdálkodás, alternatív élelmiszerrendszerek

\begin{abstract}
Operation and characteristics of the food system raise questions about what social justice means in agriculture, considering the industrial cultivation methods, labour issues and health consequences of the food system. The idea of food justice covers the whole process of the food value chain from farm to the table of consumers. The topic of food justice has been attracting great interest since the 2000s, but the number of Hungarian publications has been limited in this field. This article aims at introducing the idea and movement of food justice along with challenges of the 21st century. The
\end{abstract}

1 A projektet támogatja az EFOP-3.6.2-16-2017-00007 sz. kutatási projektben a „Társadalmi innovációk szervezeti szintű elemzése és fejlesztése" c. alprojekt. Továbbá nagyon köszönjük a bírálók támogató megjegyzéseit és javaslatait, amelyek hozzájárultak a cikk végső változatának kialakításához.

2 Budapesti Corvinus Egyetem, Marketing Intézet / Marketingkutatás és Fogyasztói Magatartás Tanszék, email: agnes.neulinger@uni-corvinus.hu

3 ELTE Eötvös Loránd Tudományegyetem Pszichológiai Doktori Iskola, ELTE Eötvös Loránd Tudományegyetem Pszichológiai Intézet, ELTE Eötvös Loránd Tudományegyetem Egészségfejlesztési és Sporttudományi Intézet, email: birtalan.liliana@ppk.elte.hu 
paper demonstrates food justice from both producer and consumer points of view and also presents the concept of alternative food networks that may help fight injustice of food production and consumption.

Keywords: food justice, consumer, producer, local food, alternative food networks

\section{Bevezetés}

Az elmúlt egy évszázadban gyökeresen megváltozott a mezőgazdasági termelés gyakorlata, intézményes környezete, és ehhez kapcsolódóan átalakultak az élelmiszerfogyasztási szokások is. Ez a változás aktualitást ad azoknak a kutatási kérdéseknek, amelyek az élelmiszer-termeléséhez, illetve fogyasztói oldalról az étkezéshez, az élelmiszerhez kapcsolódó döntéshozatalhoz és fogyasztáshoz kötődnek.

A mezőgazdaságban végbement iparosítást követően megnőtt az agrárgazdaságok mérete, az élelmiszer-kereskedelem globalizálódott, az ellátási lánc hosszabb lett, és mindezekhez kapcsolódóan eltávolodott egymástól a termelő és a fogyasztó (Lyson 2004, Obach-Tobin 2014). A globális trendekkel párhuzamosan Magyarországon is megfigyelhető a változás, azaz a 20. század végén jelentős átalakulás történt az agrárszektor termelói és fogyasztói oldalán egyaránt. Egyrészt drasztikus változások zajlottak a 90-es években a mezőgazdasági termelés intézményi kereteiben, tekintettel arra, hogy az óriásméretű szövetkezetek megszúntek, helyettük kisebb szervezetekben és vállalkozásokban - részben családi vállalkozásokban folyt tovább a mezőgazdasági termelés két birtokforma (törpegazdaságok és mezőgazdasági nagyüzemek) egymás mellett élésével (Harcsa 2016, Harcsa et al. 1994). Másrészt a 90-es évektől teret nyerő élelmiszeripari árubőség magával hozta a szezonon kívül elérhető és a világ minden tájáról származó mezőgazdasági termények széles választékát, amely a kereskedelem fejlődésének köszönhetően könnyen elérhetôvé is vált a fogyasztók számára. Ennek eredményeképpen a korábban háztáji gazdálkodást folytató magyar lakosság egyre inkább abbahagyta a gazdálkodást és vált a kiskereskedelem bolthálózatában elérhető mezőgazdasági áruk vásárlójává (Báti 2017). A különböző folyamatok összeredményeként a rendszerváltást követő húsz év a hazai agráriumban a családi vállalkozások elsorvadását hozta, miközben a hazai termékek kiszorultak a hazai piacról (Lányi 2010). További jellemzője a hazai mezőgazdaságnak az utóbbi években kialakult földbirtok-koncentráció, amelyet elsősorban vertikális együttmúködések kísérnek a kisebb mértékben megjelenő horizontális együttmúködések mellett, ahogy azt a Kovács Katalin által szerkesztett kötet esettanulmányai mutatják (Kovács 2016).

A nagyüzemi mezőgazdálkodásból származó élelmiszer egyik jellemzője, hogy a fogyasztóknak kevés beleszólásuk van abba, hogy mit és hogyan termelnek meg az élelmiszeripari vállalatok, és milyen termékek találhatók a boltok polcain. Ugyanakkor folyamatosan kerülnek be a hírekbe különböző élelmiszeripari botrányok (jellemzően az előállítás körülményei és a higiéniai viszonyok okán), amelyek hatására a fogyasztók elkezdenek egyre inkább odafigyelni az áruk származására és 
a különböző élelmiszerek jellemzőire (Beulens et al. 2005). Ennek a növekvő tudatosságnak a részeként a fogyasztók keresik a biztonságos ételeket és azokat a tanúsítványokat, átlátható folyamatokat és termékjellemzőket, amelyek ezt biztosítják (Totth et al. 2019). Továbbá a fogyasztói oldal esetében meghatározó szerep jut az ételválasztás szimbolikus jelentőségének és az értékkifejezés lehetőségének az étkezésen keresztül (Neulinger et al. 2020b), valamint a fogyasztói társadalom valóságában meghatározó a kényelmi döntések jelenősége és ennek befolyása az étkezési szokásokra (Yale-Venkatesh 1986). Emellett egyre nagyobb figyelem irányul az árutermelés körülményeire és a kereskedelem igazságosságára is a fair trade mozgalmon keresztül (Wheeler 2012), valamint a globális kereskedelem ökológiai lábnyoma kapcsán (Andersson-Lindroth 2001).

A mezőgazdasági termelés nagyüzemivé válása együtt járt a környezetet, az élővilágot és a fogyasztók egészségét veszélyeztető termelési gyakorlatokkal (úgymint a terméscsökkenésből fakadó veszteségek mérséklésére alkalmazott növényvédő szerek és múvelési technikák), amelyek ráirányították a figyelmet az élelmiszerellátáshoz és élelmiszerrendszerhez kapcsolódó igazságossági kérdésekre (ObachTobin 2014). Az élelmiszer-igazságosság témaköre szervesen kapcsolódik a társadalmi igazságosság kérdéséhez, továbbá értelmezhető a környezetvédelem, a fenntarthatóság és a társadalmi mozgalmak, valamint az agrármozgalmak világához kapcsolódóan is. A témakör vizsgálata a 2000-es években került egyre inkább az érdeklődés középpontjába, az egyik első áttekintő munkát az ideáról és kapcsolódó mozgalomról Robert Gottlieb és Anupama Joshi publikálta 2010-ben megjelent könyvében. Ugyanakkor magyar nyelvú publikáció alig akad a témában, a kivételek közé tartozik Málovics György (2012) munkája, amely a környezetvédelem és társadalmi igazságosság témájához kapcsolódva vizsgálja az élelmiszer-igazságosságot, valamint Czagány László (2009) és Balázs Bálint (2020) tanulmánya, amelyek az élelmiszer-önrendelkezéssel összefüggésben érintik az igazságosság szempontját is. Továbbá számos tanulmány készült az alternatív élelmiszer-ellátási hálózatokhoz (Alternative Food Network, AFN) kapcsolódóan, amelyek alulról építkező kiutat jelenthetnek az élelmiszer-igazságosság kapcsán. Erre példák Balázs et al. (2016), Bársony (2020), Birtalan et al. (2020) és Neulinger et al. (2020a) munkái.

Gottlieb és Joshi (2010) alapján az élelmiszer-igazságosság témaköréhez tartozik, hogy az élelmiszert hol és hogyan termesztették/termelték, kiknek a közremúködésével és milyen feltételek mellett zajlott a termesztés/termelés, beleértve a legelső lépést, azaz a magok elvetését / az állatok szaporítását, a növekedés folyamatát és körülményeit, a termés begyüjtését / az állatok levágását, az alapanyagok feldolgozásának módját, a szállítást és a végső fogyasztó asztaláig való eljutást is beleértve. Ez az ún. „from farm to table” megközelítés ezzel lefedi az élelmiszerellátási lánc összes állomását, aminek megfelelően az élelmiszer-igazságosságért fellépő mozgalmak is ennek a folyamatnak az összes kapcsolódó területét érintik (Levkoe 2006). 
Mindezt követve jelen tanulmány az élelmiszer-igazságosság kérdését a társadalmi igazságossághoz kapcsolódóan és az élelmiszerrendszer teljességének vonatkozásában tárgyalja, amely magában foglalja az élelmiszer-ellátási lánc szereplőit és az élelmiszerrendszer kapcsolódó területeit, benne az emberek és a természet viszonyát. A tanulmány célja, hogy bemutassa az élelmiszer-igazságosság kérdéskörét, valamit kitérjen azokra az aktuális kihívásokra, amelyek a 21. század mezőgazdaságát érintik az igazságosság tekintetében. Ehhez írásunk áttekinti az élelmiszerigazságosság ideológiai alapjait, majd részletesen értékeli azt elsősorban termelői és fogyasztói oldalról. Ezután kerülnek bemutatásra az alternatív élelmiszer-ellátási rendszerek, amelyek megoldást kínálhatnak az élelmiszer-termeléshez és -fogyasztáshoz kapcsolódó igazságtalanságok megszüntetésére. A szakirodalmi áttekintés az élelmiszer-igazságosság témaköréhez kapcsolódó irodalmakra terjed ki. A válogatás azokból az EBSCO-adatbázisban és a Google Scholar oldalon elérhető forrásokból indult ki, amelyek a „food justice”, „social justice”, élelmiszer-igazságosság és társadalmi igazságosság keresőszavakra megjelentek. Csak angol és magyar nyelvú szakcikkek és könyvek kerültek feldolgozásra a megjelenési idő korlátozása nélkül, de figyelve arra, hogy az irodalmi áttekintés minél több, az utóbbi öt évben megjelent munkát tartalmazzon. A végső válogatás az egyes források tartalmi megfelelőssége és fontossága (hivatkozások száma) szerint alakult ki.

\section{Az élelmiszer-igazságosság agendája}

Az igazságosság "filozófiai és társadalomelméleti kérdés” (Örkény-Székelyi 1999: 88), a társadalmi igazságosság pedig annak garanciája, hogy mindenki egyenlő eséllyel és az emberhez méltó élet biztosításához szükséges mértékben férhet hozzá azon javakhoz és szolgáltatásokhoz, amelyek lehetővé teszik, hogy stabilan, biztonságban és teljes jogú állampolgárként vehessen részt a társadalomban (Power 1999). Tekintettel az emberhez méltó élet eltérő értelmezésére ez kiegészíthető azzal, hogy mindez az adott társadalmi, kulturális és szociális környezetben érvényes és elfogadott normáknak megfelelően kell, hogy megvalósuljon (Örkény-Székelyi 2010). Basok és munkatársai (2006: 267) tovább árnyalják a kérdést azzal, hogy „az alapvető erőforrások egyenlő elosztásáról” beszélnek, amely „tekintettel van az emberi méltóságra és az emberek közötti különbségekre, hogy egyetlen kisebbségi csoport érdekei és nehézségei se szoruljanak háttérbe, és hogy a politikai szintér minden csoportnak lehetővé tegye, hogy elmondhassák a problémáikat."

A társadalmi igazságosság kérdésén belül az étkezéshez, élelmiszerhez kapcsolódó igazságosság különös jelentőséggel bír, hiszen ahogy Welsh és MacRae (1998: 241) fogalmaz: „az étel, mint semmilyen más jószág képes arra, hogy felébressze az állampolgári szerepvállalást, hiszen nagyon sok szálon kapcsolódik az életünkhöz”. $\mathrm{Az}$ étel nem egyszerúen áru, hanem gazdag szimbólumokban, alkalmat ad az értékkifejezésre és az érzelmi kötődés megélésére (Birtalan et al. 2019, Grasseni 
et al. 2014). Éppen ezért alkalmas arra is, hogy a korábban említett állampolgári, társadalmi szerepvállalást ösztönözze, amelyet az élelmiszerhez kapcsolódó aktivizmusnak is szoktak nevezni (Levkoe 2006). Az élelmiszer-aktivizmus lehetővé teszi az egyéneknek, hogy értékeiket követve állampolgárként kifejezzék véleményüket az élelmiszerrendszerrel összefüggésben, és ezen keresztül aktív szerepet vállaljanak a társadalomban (Levkoe 2006). Ezen túl az élelmiszer-termelésre és -fogyasztásra irányuló aktivizmus lehetőséget ad a fogyasztóknak arra is, hogy a nagyipari termelésben elvesztett egyéni kontrollt és az élelmiszerekhez kapcsolódó tudást (legalább részben) visszanyerjék (DeLind 2002, Turner-Turner 2008).

Az élelmiszerekhez kapcsolódó aktivizmus a társadalmi mozgalmak közé sorolható. Ahogy Touraine (1985) megfogalmazta, a társadalmi mozgalmak valamilyen társadalmi konfliktushoz kötődnek, amelyben megjelennek egymással szemben álló felek és a kontrollért folyó küzdelem. Az élelmiszer-igazságosság mozgalma magában foglalja az élelmiszerhez kapcsolódó aktivizmus széles spektrumát a termeléstől a fogyasztásig (Levkoe 2006), és olyan célokat tưz ki maga elé, mint az éhezés megszüntetése, a minőségi ételhez való hozzájutás joga, az élelmiszerek biztonságossága, a fenntartható élelmiszer-termelés megvalósítása, igazságos foglalkoztatás és az agroökológiai fejlődés biztosítása a mezőgazdaságban (Holt-Giménez 2010, Sbicca 2012). Továbbá tágabb kontextust tekintve az élelmiszer-igazságosság mozgalom olyan kérdésekkel is foglalkozik, mint a civil szervezetek szerepe, a lokális - globális élelmiszer/termelés diskurzus, a helyi közösségszervezés és általában az alulról szerveződő demokrácia témája (Wekerle 2004).

Cadieux és Slocum (2015: 13-14) szerint az élelmiszer-igazságosság négy kérdéskört érint: (1) a történelmi, kollektív traumák és állandóan jelen lévő társadalmi egyenlőtlenségek elismerését és az ezekkel való szembenézést, (2) olyan cseremechanizmusok kiépítését, amelyek biztosítják a közösségi bizalmat és kontrollt, (3) innovatív megoldások kialakítását a földterületekkel kapcsolatos kontroll, használat, megosztás, tulajdonlás, kezelés és megművelés eseteiben, összességében a föld ökoszisztémájában, ami lehetővé teszi, hogy a földterületek kikerüljenek a piaci spekulációk és a kihasználás alól, továbbá magában foglalja (4) egy olyan munkaügyi viszonyrendszer megteremtését, amelyben a munka kompenzációja igazságos, és amely a munkaerő összes típusát védi és támogatja.

Ahogy a fenti megközelítések is jelzik, az élelmiszer-igazságosság mozgalom kihívása, hogy az élelmiszerrendszerekhez tartozó kérdések széles spektrumát fedi le, így sokféle értelmezésre ad lehetőséget. A fogalom sokrétű jelentése nehézséget okozhat mind elméleti - azaz a témáról szóló tudományos diskurzus folytatása -, mind gyakorlati - azaz a mozgalomban értintett közösségek szervezeti céljainak meghatározása és az aktivisták mobilizálása - szinten (Sbicca 2012).

A sokféle cél között az élelmiszer-aktivisták számára kiemelt fontosságúak az egyén egészségével, illetve tágabb kontextusban az ökológiai egészséggel kapcsolatos célok (Alkon 2014). Utóbbit Karr (1996) úgy határozza meg, mint a mezőgaz- 
dasági célra használt területnek a kívánatos állapotát, ahol a terület hosszú távú használatát - jövőjét - nem lehetetleníti el a művelés. Alkon (2014) szerint a fenntartható mezőgazdaságért küzdő mozgalmak - amelyek az élelmiszer-igazságosság mozgalmához kapcsolódnak - aktuális céljai között szerepel, hogy egyre több helyi és ökológiai gazdálkodásból származó termék legyen elérhető a fogyasztók számára.

$\mathrm{Az}$ élelmiszer-mozgalmak egy része kifejezetten a városokban jelentkezó élelmiszer-problémákhoz kapcsolódik, és ennek részeként veti fel az élelmiszer-igazságosság mellett az élelmiszer-önrendelkezés kérdését (Clendenning et al. 2016). Az élelmiszer-önrendelkezés elsődlegesen az élelmiszerhez és annak előállításához való jogot hangsúlyozza, bár Clendenning és munkatársai (2016) jelzik, hogy a fogalom folyamatosan fejlődik és változik. Balázs (2020: 83) megfogalmazásában az élelmiszer-önrendelkezés alatt mindazokat a „mindennapi gyakorlatokat és politikai stratégiákat értjük, amelyek lehetővé teszik, hogy társadalmi és ökológiai szempontokat érvényesítve, demokratikus és a külső sokkoknak ellenálló módon szervezzük meg az élelmiszer-gazdaságot”. A két mozgalom (élelmiszer-igazságosság és élelmiszer-önrendelkezés) számos ponton kapcsolódik egymáshoz, de ahogy Clendenning és munkatársai (2016) megállapítják az élelmiszer-önrendelkezés mozgalom számára a politikai alapú, az élelmiszeripar üzleti logikája ellen fellépő megközelítés a hangsúlyosabb, amely rendszerszintű változást céloz, míg az élelmiszer-igazságosság a társadalmi igazságosság szempontjából foglalkozik a témával azzal együtt, hogy állampolgári politikai szerepvállalásra is ösztönözhet. Cadieux és Slocum (2015) hasonlóképpen különbözteti meg a fogalmakat, kiemelve, hogy az élelmiszer-önrendelkezés központi alapvetése a szabadsághoz kötődik, és radikális politikai kapcsolódása van, míg az élelmiszer-igazságosság középpontjában konkrét programok és helyi kezdeményezések megvalósítása áll. Vagy ahogy Alkon és Mares (2012) megfogalmazza a különbséget: az élelmiszer-igazságosság mozgalma az egyenlőtlenségért az adott kormányt/vezetést, és nem a kapitalizmust hibáztatja, azaz alternatív élelmiszerrendszert akar létrehozni, és nem politikai reformot, szemben az élelmiszer-önrendelkezésért küzdőkkel. A különbségek ellenére mindkét mozgalmat a társadalmi igazságosság vezérli, és mindkettő szorgalmazza az állampolgári szerepvállalást. Továbbá mindkettőt ösztönzi az élelmiszer-ellátás megváltoztatása, de a kiindulópontjuk eltérő. Amíg az élelmiszer-önrendelkezés a tőke múködését kritizálja az élelmiszerrendszerben, addig az élelmiszer-igazságosság az egyenlőtlenségben látja a probléma forrását (Alkon-Mares, 2012, Allen 2008). Végcéljaikat tekintve az élelmiszer-önrendelkezés mozgalma az élelmiszerrendszer megváltoztatásának igényét fogalmazza meg - ennyiben tekinthető radikálisan politikaibbnak -, míg az élelmiszer-igazságosságért küzdők esetében csak a mozgalomnak egy része jut el eddig a kritikáig (Holt-Giménez-Wang, 2011). Mindezzel együtt az is elmondható a két megközelítésről, hogy a gyakorlatban gyakran együtt érvényesülnek, és jelentésük is összemosódhat (Cadieux-Slocum 2015). 
A továbbiakban az élelmiszer-igazságosság kérdését az élelmiszer-értéklánc két fontos szereplője, a termelő és a fogyasztó nézőpontjain keresztül mutatjuk be.

\subsection{Az élelmiszer-termelés igazságossága}

Gottlieb és Joshi (2010) könyve az élelmiszerrendszer igazságtalan oldalának bemutatását a mezőgazdaságban dolgozók méltatlan helyzetének feltárásával kezdi, ami a 60-as évek Észak-Amerikájában különösen problémás volt a bevándorlók foglalkoztatása kapcsán. Az akkori idők munkását az amerikai farmokon a szegénység, az éhezés és a vegyszereknek való kitettség egészségügyi kockázatai jellemezte. Nem meglepő, hogy az élelmiszer-igazságosság egyik alapkérdését a farmokon dolgozók problémáinak megoldása jelentette abban az időben. Ahogy Gottlieb és Joshi (2010: 116) megfogalmazta könyvében: „az élelmiszer-igazságosság támogatói sürgetik a földterület és a természeti környezet tiszteletét, amelynek földjét, vizét, levegőjét kihasználják a mezőgazdaság meghatározó nagyipari szereplői”.

A gazdaságokban dolgozók emberhez nem mindig méltó életkörülményei és munkaerejük kihasználása a mai napig releváns kérdés az élelmiszer-termelés igazságossága kapcsán. A témában megjelent kutatások között említhető Perry (2019) munkások esetében érinti a mezőgazdaságban jelen lévő igazságtalanságot.

Ezeken felül a termelés igazságosságához kötődően felmerül a globális rendszerek problémája, amelynek értelmében az igazságtalanság egyaránt érinti a fejlett és a fejletlen világ, vagy a világrendszer-elmélet szerint a centrum és a periféria országainak agráriumát. Egyes vélemények szerint a helyzetet súlyosbítják a mesterséges világpiaci árak, ahogy McMichael (2019: 169) megfogalmazza: „a túltermelés és a mezőgazdasági export általánossá vált rendszere mesterségesen lenyomja a mezőgazdasági termékek árát, és aláássa a földgazdálkodást mindenhol”. Gottlieb és Joshi (2010) érvelése szerint mindez tönkreteszi a kistermelőket, és egyúttal a korábban már jelzett alacsony bérekért és nem megfelelő munkakörülményekért is felelős. Sharman (2007) véleménye szerint a klímaváltozás problémája lesz az, ami végül majd véget vet a szabadkereskedelem uralmának. Ahogy tanulmányában jelzi, ha a fenntarthatóság célja meghatározóvá válik a globális politikai agendában, akkor az „megöli és eltemeti” a szabadkereskedelem paradigmáját, és elhozza a fenntarthatóság szempontjából kialakított szabályozás rendszerét.

Összességében a termelés igazságossága azt kívánná meg, hogy a termelők munkáját a piac megfelelően kompenzálja, valamint munkajogi helyzetük és munkakörülményeik is rendezettek legyenek. Minkoff-Zern (2017) szerint ehhez szükséges lenne, hogy az élelmiszer-mozgalmak civil támogatói ne csak szúken a fogyasztói és a kistermelői érdekekre figyeljenek, hanem legyenek kritikusak a mezőgazdasági termelés egészével szemben, beleértve a nagyüzemekben és a feldolgozóiparban foglalkoztatottak helyeztét is. A fogyasztók felelősségét nevesítik Allen és munkatársai (2003) akik az élelmiszer-igazságosság érdekében szükségesnek tartják, hogy a fogyasztók hajlandóak legyenek magasabb árat fizetni azokért a ter- 
ményekért, amely biztosítják a kisebb gazdaságok túlélését. Tehát ez a megközelítés a piaci verseny keretein belül maradva a fogyasztó vállára teszi a felelősséget. Kérdéses azonban, hogy a fogyasztói felelősségvállalás önmagában meg tudja-e oldani az igazságosság problémáját, hiszen amennyiben a fogyasztók egy része el is fogadja a magasabb fogyasztói árakat, ennek következménye lehet, hogy az így megtermelt élelmiszer jellemzően megfizethetetlenné válik az alacsonyabb jövedelműek számára. A termelők igazságosabb kompenzálása ebben az esetben a fogyasztói hozzáférés megnehezítésével jár, amely az ő szempontjukból az elérés igazságosságát csökkenti. Másrészt ennek ellenkezőjeként a kedvezőbb árak kialakítása sem feltétlenül reális elvárás a piaci verseny keretein belül, hiszen a kisüzemi méret és a munkaigényes termelés költségei így nem kompenzálhatók (Alkon-Mares 2012).

\subsection{Az élelmiszer-fogyasztás igazságossága}

A fenti gondolatot folytatva a termelés és fogyasztás piacgazdasági kontextusa behatárolja az élelmiszer-igazságosság elérésének útjait, amennyiben a fogyasztók egyéni felelősségüket kifejezve vásárlási döntéseikkel - „dollárszavazatukkal” tudják támogatni vagy nem támogatni az élelmiszer-igazságosságot (Alkon 2014). Ennek része, hogy a vevők honnan és milyen feltételekkel vásárolnak, azaz elfogadják-e szabadkereskedelem okozta nemzetközi termékdömpinget, támogatva a nyomott mezőgazdasági termelői árakat (McMichael 2019), vagy fair trade termékeket vásárolnak (Wheeler 2012), illetve előnyben részesítik a kisüzemi mezőgazdasági termelésből származó árukat (Holt-Giménez 2010).

Másik nézőpontból a mezőgazdasági termékek fogyasztói igazságossága felveti a termékminőség és a fogyasztói hozzáférés igazságosságának a kérdését. ${ }^{4} \mathrm{~A}$ termékminőség és hozzáférés elsődlegesen élelmiszer-biztonsági kérdésekre és az egészséges élelmiszerhez való hozzáférés jellemzőire vonatkozik (Werkheiser-Noll 2014). A hozzáférés igazságossága magában foglalja a minőségi élelmiszerhez való hozzájutás lehetőségeit (korlátait), beleértve azok árát és fizikai elérhetőségét. Mindez kapcsolódik ahhoz, hogy kik vesznek részt az élelmiszer-mozgalmakban, valamint kik tematizálják azokat. Sbicca (2012) szerint az élelmiszer-mozgalmak aktivistái és támogatói elsődlegesen a középosztályból kerülnek ki, és általában is elmondható, hogy az élelmiszer-igazságosság témája, valamint az alternatív - nem a hagyományos, nagyüzemi rendszerből származó - élelmiszer-elosztással foglalkozó diskurzus inkább a magasabb státuszú, a földmúveléstől hagyományosan távolabb álló csoportok számára érdekes (Guthman 2008). Amennyiben a magasabb minőségúnek és egészségesebbnek tartott helyi, kistermelői élelmiszer-fogyasztók jellemzőit nézzük, akkor nemzetközi (például Kneafsey et al. 2013) és hazai (például Balázs et al. 2016) elemzésekből kiderül, hogy ők a fiatal, magasabb státuszú

4 A fogyasztók érintettsége az élelmiszer-igazságosságban másképp jelentkezik a gazdaságilag fejlett és a fejletlen országok vagy a világrendszer-elméletet tekintve a centrum és a periféria országai esetében (Éber et al. 2019). Jelen tanulmány a fogyasztói részvétel kérdését csak az előbbi országok fogyasztóinak helyzetén keresztül értelmezi, amely csoportba Magyarország is tartozik, de a fejletlen és periférián lévő országok fogyasztóival külön nem foglalkozik. 
és végzettségú, extrovertált, városi és tudatos fogyasztók közül kerülnek ki, akik sokszor családosak, és elutasítják a fogyasztói társadalom nagyüzemi megoldásait. Tehát fogyasztói oldalról az átlaghoz képest egy anyagilag jobb körülmények között élő csoport értékeli és tudja megfizetni az igazságosabbnak tartott mezőgazdasági termelést, ami annak is köszönhető, hogy a fogyasztói társadalom keretein belül és a fogyasztói döntéssel összefüggő igazságosság nézőpontjából ők rendelkeznek az ehhez szükséges anyagi háttérrel és hozzáféréssel (Holt-Giménez-Wang, 2011). Továbbá elmondható, hogy ez a fogyasztói csoport motivációját tekintve nem egységes. Ahogy azt a témával foglalkozó kutatások jelzik, a fogyasztók sokszor az egészséges ételhez való hozzáférés miatt, és nem az igazságosság okán vásárolnak helyi, kistermelői mezőgazdasági termékeket (Balázs et al. 2016, Neulinger et al. 2020a, Török et al. 2020).

$\mathrm{Az}$ előzőekhez kapcsolódóan és kifejezetten városi kontextusban az élelmiszerigazságosság további kérdése: hogyan lehet úgy megtermelni és eljuttatni a városi környezetben élő szegényeknek az élelmiszert, hogy az számukra elérhető és megfizethető legyen (Clendenning et al. 2016). Hiszen ahogy Dixon (2014: 183) megállapítja, a marginalizált csoportok, akik a társadalom számára „láthatatlanok, szegények, és nincs politikai erejük”, nehezen tudnak hozzáférni minőségi élelmiszerhez. Igaz, az élelmiszer különböző jótékonysági akciókon keresztül eljuthat azokhoz is, akiknek különben anyagi nehézséget okoz az élelmiszerek beszerzése, de ezek nem feltétlenül minőségi termékeket jelentenek. Amennyiben a helyi kistermelők ilyen módon is támogatják terményeikkel a helyi közösséget, lehetővé teszik azt, hogy az egészséges, tápanyagban gazdag, friss, sokszor organikus terményekhez a társadalom leszakadó részei is hozzáférjenek. Ezzel a megoldással a magas árak okozta hozzáférési korlát részben felszámolhatónak tűnik. A közvetítést végezhetik civil szervezetek, így az Egyesült Államokban azok az élelmiszerbankok, amelyek a konvencionális élelmiszer helyett helyi terményeket juttatnak el a rászorulóknak (DuPuis-Goodman 2005). Továbbá az egészséges élelmiszerhez való hozzájutást teszik lehetővé azok a megoldások is, amelyek az élelmiszerek saját megtermelésének lehetőségét viszik el a társadalom szélén élőkhöz (Meenar-Hoover 2012). Ez valósul meg az úgynevezett „városi mezőgazdaság” formájában, ami városokban kijelölt és múvelési célra kialakított földparcellákon, kertekben történő gazdálkodást jelent (Meenar-Hoover 2012). Az így kialakuló közösségi kertek a kertészkedést biztosítják azok számára, akik saját kerttel/ földterülettel nem rendelkeznek, de szeretnének maguknak élelmiszert termelni. A közösségi kertek tagjai kis parcellával rendelkeznek, amelyet maguk művelnek meg, és ezzel az is lehetővé válik a városlakók számára, hogy fizikailag és közösségileg is aktívak legyenek (Burt et al. 2021, Kingsley et al. 2009) miközben az alacsonyabb státuszú csoportok is részesülhetnek a minőségi élelmiszerekből (Martin et al. 2017). Magyarországi viszonylatban Bársony (2020) azt állapította meg a közösségi kertekről, hogy működésüket elsősorban az egyéni célok határozzák meg, miközben a közösségi cselekvés és a közös eszme nem jellem- 
ző. Ezzel együtt azon kertek esetében, ahol a tagok között vannak alacsony jövedelmű, idősebb/nyugdíjas tagok is, megvalósul az egészséges ételhez való hozzáférés biztosítása a közösségi kerti tagságon keresztül.

A tágabb hazai kontextust tekintve számos olyan szervezet található Magyarországon, amely az élelmiszer-fogyasztás igazságosságának érdekében is végzi tevékenységét. A teljesség igénye nélkül ezek közül kiemelhető a 2000 márciusában megalakult ökopolitikai szervezetet, a Védegylet, amely az egyik legrégebbi a környezeti- és társadalmi igazságosságért küzdő hazai civil szervezetek között. A Védegylet munkacsoportjai - többek között - aktívak a fair trade és az élelmiszer-önrendelkezés területein (www.vedegylet.hu). Hasonlóan nagy múltú hazai szervezet a Tudatos Vásárlók Egyesülete, amely 2002 óta dolgozik az igazságos és szolidáris társadalom megteremtésén olyan projekteken keresztül is, mint a közösségi mezőgazdálkodás segítése és a klímabarát élelmiszer-termelés népszerűsítése (www.tudatosvasarlo.hu). Az élelmiszer-termelés és fogyasztás problémáira kínál megoldást a permakultúra terjesztését célzó Magyar Permakultúra Egyesület, amely 2006 óta végzi a permakultúrás gondolkodás és gazdálkodás gyakorlását és terjesztését (permakultura.hu). Az újabb szervezetek között említhető a 2012-ben létrejött Magház és a 2014-ben alakult Kislépték szervezet. A Kislépték, azaz a Kisléptékű Termék-előállítók és Szolgáltatók Országos Érdekképviseletének Egyesülete tevékenységében - mások mellett - megjelenik a kistermelői élelmiszer-termékek előállításának és értékesítésének támogatása, a rövid ellátási lánc ösztönzése (kisleptek.hu). A Magház, teljes nevén Magház Közösségi Hálózat a Mezőgazdasági Sokféleségért szervezet a hazai agrobio-diverzitás megőrzéséért dolgozik, és fenntart többek között olyan magbankokat, amelyek különböző növényfajták szaporítóanyagait őrzik és teszik elérhetővé a lakosság számára (maghaz.hu). Ezek mellett számos olyan civil szervezet is múködik hazánkban, amelyeknek az élelmiszer-igazságossághoz kapcsolódó tevékenysége egyúttal az akadémiai kutatáshoz is kapcsolódik. Erre példa a Szolidáris Gazdaság Központ, amelynek a működése erős társadalomelméleti alapokon és rendszerkritikán nyugszik. A szolidáris gazdaság modelljét népszerűsítő hálózat az élelmiszer-ellátással összefüggő projekten is dolgozik, amelynek célja egy olyan élelmiszerrendszer megteremtése, amely demokratikusan szervezett, szolidáris elveket követ, és környezetileg fenntarthatóan múködik (szolidarisgazdasagkozpont.hu). A terület meghatározó akadémiai szereplője a Közgazdaság- és Regionális Tudományi Kutatóközpont, amely más területek mellett foglalkozik a fenntarthatóság gazdasági, környezeti és társadalmi feltételeivel (www.krtk.hu). Emellett a kutatói világot képviseli a témában az ESSRG (Environmental Social Science Research Group) hazai szervezete. Tevékenységük középpontjában a társadalmi igazságosság és az ökológiai fenntarthatóság áll, és olyan projektekben vesznek részt például, mint az együttmúködésen alapuló élelmiszerrendszerek vizsgálata (www.essrg.hu). Végül említést érdemelnek azok a mozgalmak, amelyek jellemzően nemzetközi trendekbe illeszkednek, és céljaik az 
élelmiszer-igazságosságot is érintik. Az egyik ilyen szervezet a Budapesten is müködő Food Not Bombs mozgalom, amelynek önkéntesei élelmiszer-adományokat osztanak rászorulóknak a háborúk, a szegénység és a környezetrombolás ellen tiltakozva (www.foodnotbombs.net). További példa az agroökológia, amely társadalmi és politikai mozgalomként is meghatározható, miközben tudományos és gyakorlati vonatkozása is van. Az agroökológia mint mozgalom célja, hogy hozzájáruljon egy fenntartható és igazságos élelmiszermodell kiépítéséhez azáltal, hogy befolyásolja az élelmiszerek beszerzésének és fogyasztásának módját. A mozgalom tagjai tudatosan keresik az igazságosabb és fenntarthatóbb élelmiszer-fogyasztási lehetőségeket, és ezáltal fordulnak az alternatív élelmiszer-ellátási megoldások felé (MTVSZ 2015). Mindezeken túl említhető az élelmiszer-igazságossághoz kapcsolódó mozgalmak között az ökofalu-mozgalom, amely Magyarországon az 1990-es években indult, és a zöld mozgalmakhoz kapcsolódik. Az ökofalvak tagjai falusi környezetben törekszenek a fenntarthatóság elvei szerinti életre ökológiai, társadalmi és spirituális okoktól vezetve (Farkas 2014).

\section{A helyi termelés jelentősége az igazságosabb élelmiszer- ellátásban}

Az élelmiszerrendszer igazságtalanságaira merülhet fel válaszként a lokális termelés és fogyasztás, amely lehetőséget ad arra, hogy a fogyasztók visszavegyék kezükbe (legalább részben) a kontrollt, és olyan élelmiszert vásároljanak, amely általuk ismert forrásból származik, továbbá összetevője/termelési eljárása is megismerhető (Mount 2012). Ahogy DuPuis és munkatársai (2011: 283) megállapítják: a helyi élelmiszer-termelést propagáló mozgalmak a 2000-es évek elején egyre inkább elkezdték összekötni a helyi élelmiszerrendszereket az igazságosság fogalmával. Számos tanulmány érhető el ebből az időszakból, amelyek azt igazolják, hogy a helyi termelés és értékesítés „egyenlőbb és demokratikusabb” élelmiszer-ellátást eredményez (DuPuis et al. 2011).

A helyi termelés igazságosságát jellemzően négy okkal magyarázzák az élelmiszer-mozgalmakat vizsgáló kutatók, úgymint a lokális gazdálkodás környezeti, közösségi, gazdasági és egészségügyi előnyeivel. A környezeti előnyök kapcsolódnak a rövidebb szállítási távolsághoz és a kisebb mértékű vegyszerezéshez, amennyiben a hosszabb szállítás és eltarthatóság érdekében nem kell külön kezelni a terményeket (Werkheiser-Noll 2014). A közösségre vonatkozó előnyök a szolidaritást, a gazdafogyasztó kapcsolat minőségét és általában a helyi közösség életminőségét helyezik a középpontba. Ahogy Feenstra (1997: 28) megjegyzi, „annak a módja, ahogy az élelmiszer termelése, elosztása és elfogyasztása zajlik, alapvetően meghatározza a közösség környezeti, társas, spirituális és gazdasági jóllétét”. A helyi termelésnek lehetnek pozitív gazdasági következményei, hiszen amennyiben a vevők helyi gazdáktól vásárolnak, akkor a globális rendszerek helyett pénzükkel a kistermelőket 
támogatják (Lockie 2009). Szente et al. (2021) szisztematikus metaelemzése igazolta a helyi élelmiszer-termelés és -fogyasztás pozitív gazdasági hatásait elsősorban a foglalkoztatással és a jövedelmek növekedésével összefüggésben. Egészségügyi szempontból a helyben múködő élelmiszerrendszerek megkönnyítik az egészséges élelmiszerhez való hozzáférést, és egyúttal edukálják is a vevőket az egészséges étkezésről a szorosabb termelői kapcsolatok révén (Birtalan et al. 2020, Fournier et al. 2019). Összességében a lokális élelmiszerrendszerekhez kapcsolódó fogyasztói ideológia Reich és munkatársai (2018) szerint három alapvető meggyőződésen alapul: (1) a helyi élelmiszer idealizálása, azaz a helyi élelmiszer felsőbbrendűségéről való meggyőződés, (2) szembenállás a messziről érkező élelmiszerrel, elsősorban biztonsági és átláthatósági okokból, valamint (3) az élelmiszer-gazdaság közösségivé tétele, a helyi közösség támogatása.

A bemutatott előnyök ellenére vannak a helyi termelésnek olyan sajátosságai, amelyek azt eredményezik, hogy a lokalitás önmagában nem képes orvosolni az agrárszektorban meglévő egyenlőtlenségeket. Egyrészt, ahogy Lockie (2009) rámutat: a helyi termékek vásárlói változatos okokból választják ezeket a megoldásokat, és ezek között az igazságosság és a fenntarthatóság nem feltétlenül szerepel kiemelt helyen. Márpedig ha a motiváció nem ezekhez kötődik, hanem például az egészségességhez, akkor a fogyasztók könnyen fordulhatnak olyan alternatívák irányába, amelyek egészségesek ugyan, de az ipari (globális) mezőgazdaság igazságtalan múködéséből származnak. Éppen ezt a fogyasztói igényt és a helyi termeléshez kapcsolódó pozitív asszociációkat használják azok a nagy kereskedelmi láncok, amelyek helyi termékek bemutatásával népszerúsítik magukat. Ilyen kampányokokat könynyen találni a magyar hirdetések között is. ${ }^{5}$ Másrészt a helyi rendszerek előnyeinek tartott jellemzők is megkérdőjelezhetők, amennyiben tágabb kontextusba kerülnek. Ezt jelzik tanulmányukban Edwards-Jones és munkatársai (2008), felhívva a figyelmet arra, hogy a rövidebb szállítási útvonal nem feltétlenül jelez kisebb környezetterhelést, mert a megtett kilométer alapú gondolkodás - amely sokak által használt és kedvelt mutató - nem megfelelő a teljes ellátási lánc okozta környezeti és társadalmi hatások megértésére. Ugyanerre hívja fel a figyelmet Rothwell és munkatársai (2016) elemzése, akik a teljes termékéletút figyelembevételével hasonlítottak össze lokális és globális forrásból származó élelmiszereket, és jutottak arra, hogy a környezeti terhelést befolyásoló tényezők között a szállítási távolság mellett a választott csomagolási megoldás volt a meghatározó. További kritika lehet, hogy hiába helyben valósul meg a termelés, ha a gazdálkodást intenzív vegyszerezés kíséri, negatív következményekkel a földterület minőségére és a környezetvédelemre (Allen et al. 2003).

5 Lásd például a Spar és az Aldi kampányát a hazai termékek árusítása kapcsán https://www.spar.hu/sajtokapcsolat/2020/magyar-termelokpiacrajutasatsegitiaspar és https://www.agrotrend.hu/hireink/a-magyar-termekek-arusitasara-torekszik-az-aldi 


\section{Élelmiszer-igazságosság az alternatív élelmiszer-ellátási hálózatokban}

A fogyasztók csalódása a nagyüzemi mezőgazdaságban igényt teremtett azon alternatív élelmiszer-beszerzési megoldások iránt, amelyek a fogyasztót a termelés közelébe engedik (Renting-Van Der Ploeg 2001). Jarosz (2008) szerint az alternatív élelmiszer-ellátási hálózatok megjelenése kötődik az erőteljes városiasodáshoz, benne a felértékelődő belvárosi területeken élő, magasabb státuszú lakosságnak ahhoz az igényéhez, amely a szezonális, helyi termesztésü és egészséges élelmiszerek iránt jelentkezik. Másrészt a városokhoz közeli vidéki területeket tekintve megfigyelhető a fenntartható, kistermelői (családi) gazdaságok megalakulása (Jarosz 2008).

Az alternatív élelmiszer-ellátási hálózatok magukban foglalják többek között a termelői piacokat, a közösségi kerteket, a vásárlói közösségeket és a közösségek által támogatott mezőgazdasági tevékenységeket (Neulinger et al. 2020a, Zoll et al. 2018); a részletesebb jellemzésüket lásd az 1. táblázatban.

1. táblázat: Alternatív élelmiszer-ellátási hálózatok bemutatása

\begin{tabular}{|c|c|c|}
\hline Típus & Jellemzők & Hazai példa \\
\hline Termelői piac & $\begin{array}{l}\text { Helyi vagy lokális forrásból szár- } \\
\text { mazó termékeket árusító piac.* }\end{array}$ & Czakó Piac, Szimpla Háztáji Piac \\
\hline $\begin{array}{c}\text { Közösség által támogatott mező- } \\
\text { gazdaság }\end{array}$ & \begin{tabular}{|c|} 
Tartós elkötelezettség termelő \\
és fogyasztó között, a fogyasztó \\
előzetesen anyagilag támogatja a \\
termelőt a jövőbeli terményekből \\
való részesedésért.
\end{tabular} & $\begin{array}{l}\text { Háromkaptár Biokert http:// } \\
\text { haromkaptar.hu }\end{array}$ \\
\hline Vásárlói közöségek & $\begin{array}{c}\text { Fogyasztók önszerveződése, } \\
\text { termelői áruk beszerzésére és a } \\
\text { tagok közötti kiosztásra. }\end{array}$ & $\begin{array}{c}\text { Szatyorbolt } \\
\text { http://szatyorbolt.hu/bevasarlo- } \\
\text { kozosseg }\end{array}$ \\
\hline Közösségi kert, saját ellátásra & \begin{tabular}{|c|} 
A tagok területet bérelnek egy \\
közös termőterületen belül, ahol \\
maguk vetnek és aratják le a \\
termést elsősorban saját fogyasz- \\
tásukra.
\end{tabular} & $\begin{array}{c}\text { Grundkert, Első Kispesti Kert, } \\
\text { Csárdás Kert }\end{array}$ \\
\hline Közösségi kert, üzleti célból & $\begin{array}{c}\text { A tagok területet bérelnek egy } \\
\text { közös termőterületen belül, ahol } \\
\text { maguk vetnek és aratják le a } \\
\text { termést eladási célból. }\end{array}$ & Magyarországon nem jellemző. \\
\hline $\begin{array}{c}\text { Nonprofit szervezet által működ- } \\
\text { tetett közösségi kert oktatási és/ } \\
\text { vagy integrációs céllal }\end{array}$ & $\begin{array}{c}\text { A szervezet területet biztosít a } \\
\text { közösség számára, ahol a tagok } \\
\text { közösen fogyasztják el a megter- } \\
\text { melt élelmiszert. }\end{array}$ & $\begin{array}{c}\text { A Mahájána Alapítvány kertje } \\
\text { Csörögön } \\
\text { http://www.mahajana-alapitvany. } \\
\text { hu/egyeb-programok/kiskert- } \\
\text { program/ }\end{array}$ \\
\hline
\end{tabular}

* Jogszabályi szinten a kereskedelemről szóló, 2005. évi CLXIV. szabályozza a termelôi piacokat.

Forrás: Neulinger et al. 2020a

Az alternatív élelmiszer-ellátó hálózatok célja, hogy a nagyipari mezőgazdasággal szemben környezetileg fenntartható, gazdaságilag életképes és társadalmilag igazságos élelmiszer-termelést hozzanak létre (Allen et al. 2003). Az alternatív élelmiszerellátó hálózatok - tekintettel a közeli termelő és fogyasztó kapcsolatokra - lehetôvé 
teszik, hogy a fogyasztók bizonyos mértékben visszanyerjék a kontrollt az élelmiszergazdasági mechanizmusok/döntések felett (Forno-Graziano 2014). Ezáltal az alternatív élelmiszer-hálózatok felhatalmazzák a fogyasztókat, hogy aktív részesei legyenek a mezőgazdasági termelésnek, vagyis ezzel demokratizálják annak folyamatát (Renting et al. 2012). Az alternatív élelmiszer-ellátó hálózatok lehetőséget adnak arra, hogy a fogyasztók kifejezzék értékeiket a vásárláson keresztül, miközben a közösségi interakciók során tanulási folyamaton is keresztülmennek. Mindez a termelók és a fogyasztók közötti viszony átalakulását eredményezi a közöttük lévő távolság csökkenésével és az együttmúködésük erősödésével (Balázs et al. 2016, Renting et al. 2012).

A gazdák jellemzően akkor fordulnak az alternatív élelmiszer-hálózatok felé, amikor szembesülnek saját versenyképtelenségükkel az agrár-tömegtermelés piacán, beleértve a megélhetés anyagi bizonytalanságát (Renting et al. 2003). A fogyasztói motivációkat tekintve Zoll és szerzőtársai (2018) megemlítik (1) a magas minőségủ élelmiszerekhez való hozzáférés lehetőségét (íz, frissesség tekintetében), (2) az egészségügyi okokat, (3) a politikai/állampolgári érték kifejezésének a módját, (4) a környezetvédelmi szempontokat szembeállítva a nagyüzemi mezőgazdasággal, (5) a szolidaritást, azaz a kistermelők támogatását, valamint (6) a közösségépítési, részvételi szempontokat. Kutatásukból kiemelésre érdemes, hogy a fogyasztói motivációk között elsődlegesnek találták az egyéni szempontokat, míg a közösségi és társadalmi szempontok másodlagosak voltak. Ezzel együtt Feagan és Morris (2009) munkája szerint fontos az alternatív élelmiszerrendszerek társadalmi és lakóközösségi beágyazottsága is. Hazai viszonyok között az egyéni és közösségi szempontok kettősségét Balázs és munkatársai (2016) a fogyasztói motivációk időbeli átalakulásával magyarázzák, amely leköveti az alternatív élelmiszer-ellátási hálózatok iránti elköteleződés megerősödését az idő múlásával. Tanulmányuk szerint ezen hálózatokhoz való csatlakozás fỏ oka a friss, egészséges, helyi és organikus termékek vásárlása megbízható forrásból, míg a közösségi és szolidaritási szempontok háttérbe szorulnak. A későbbiekben azonban ez megváltozik, és egyre fontosabbá válnak a közösségi kapcsolatok, esetenként barátságok és a jó ügy (a kistermelők) támogatása.

A fogyasztói részvételi motiváció az egyes alternatív élelmiszer-ellátási hálózatokban a fogyasztói részvétel szintjei szerint eltérő lehet. Venn és munkatársai (2006) szerint a fogyasztók egyrészt betölthetik a termelói szerepet, amennyiben az elfogyasztott élelmiszert egyúttal ők termelték meg, amennyiben közösségi kertek tagjai. Másrészt a fogyasztók szoros együttmúködésben lehetnek a termelókkel, ezt példázza a közösség által támogatott mezőgazdaság, ahol a fogyasztók átvállalják a termelés kockázatát a várható termés reményében egy előzetes, jellemzően éves előfizetési rendszerben a tényleges termeléstôl függetlenül. Harmadrészt a direkt értékesítési megoldások esetén a fogyasztó az árut offline vagy online rendeléssel közvetlenül a termelőtől veszi át termelői piacokon vagy heti dobozos rendelések során. Ezek a megoldások eltérő szintű fogyasztói bevonódást engednek a termelésbe 
és ezáltal a gazda-fogyasztó kapcsolatba, vagyis különböző fogyasztói szegmensek számára lehetnek vonzóak.

Az élelmiszer-igazságosság szempontjából lényeges szempont, hogy az alternatív élelmiszer-hálózatok gyakran követnek vegyszermentes termelést, és módszereik megfelelnek az ökológiailag fenntartható termelés követelményeinek (Evans et al. 2002). Ezzel együtt ezek az élelmiszerrendszerek sem képesek az agrárium társadalmi és gazdasági - globálisan érzékelt - igazságtalanságait helyi szinten teljes körűen megoldani (Watts et al. 2005). Ezt példázza Allen és munkatársai (2003) kutatása kaliforniai alternatív élelmiszer-hálózatok esetében, amiből kiderül, hogy az alternatív élelmiszerrendszer számos eredménye - például az ételhez való hozzáférés lehetősége, kis gazdaságok támogatása - mellett a farmokon dolgozók esetében az igazságosságot nem tudta biztosítani, beleértve a bérezés, a munka biztonsága és a munka elismertségének kérdéseit. Az alternatív rendszerek igazságosságának szempontjából figyelembe kell azt is venni, hogy az ezen rendszerek keretében termelő gazdák számos gazdasági kihívással szembesülnek. Ezek a rendszerek - működési modelljüket tekintve alapvetően a közvetlen értékesítésre és a felek közötti személyes kapcsolatra építenek, ami magas költséggel (szállítás, munkaerő) és megnövekedett időigénnyel jár (Jarosz 2008). Végső soron ezek a termékek az áraikban sokszor nem versenyképesek a nagyipari helyi és nemzetközi mezőgazdasági szereplők termékeivel. Az erős verseny és a farmerek erős elköteleződése és kötelességtudata az általuk kiszolgált közösség felé gyakran ahhoz vezet, hogy kizsákmányolják önmagukat, ami az alternatív élelmiszerrendszerek fennmaradását veszélyezteti (Galt 2013).

Magyarországon az alternatív élelmiszer-beszerzési megoldások még fejlődési szakaszuk elején járnak (Balázs et al. 2016), ezzel együtt az alternatív élelmiszerrendszerek hazai elterjedésének kérdése azért is jelentős, mert Magyarország tipikusan olyan ország, ahol a társadalmi kapcsolatok szintje, a civil aktivitás mértéke és a környezet minősége alacsonynak tekinthető, hasonlóan a szubjektív jóllét alacsony szintjéhez (OECD 2011). Ebben a helyzetben egy olyan élelmiszerrendszer, amelyben megjelenik a szolidaritás, valamint jelentősek a közösségi kapcsolatok az egészséges élelmiszerhez való hozzáférés lehetőségén keresztül, javíthatná az országra jellemző, említett kedvezőtlen tendenciákat.

\section{Következtetések}

Tanulmányunk kérdésfeltevése az volt, hogy lehetséges-e az élelmiszer-igazságosság elérése, azaz igazságos lehet-e az élelmiszerrendszer a termelőtől a fogyasztó asztaláig tekintve. A kérdésre a válasz a kapcsolódó szakirodalom áttekintése alapján az, hogy az élelmiszer-igazságosság egy-egy szempontot tekintve elérhetőnek túnik. Az elmúlt években számos sikeres programot valósítottak meg a különböző élelmiszer-mozgalmak aktivistái például a minőségi élelmiszerek fogyasztói hozzáférése (Meenar-Hoover 2012, Vitiello et al. 2015) és a farmokon dolgozók támoga- 
tása (Clendenning et al. 2016, Perry 2019) kapcsán. Azonban ezek részleges célok, amelyek sikeresek a helyi, az ökológiai vagy a kisüzemi termelés és fogyasztás támogatásában, miközben ritkán jelentenek megoldást az élelmiszerrendszer tágabban felvethető problémaira (Minkoff-Zern 2017). Komplex rendszerszintű megoldást vázol fel Alkon (2014) az élelmiszer-igazságosság eléréséhez, amelyben javasolja az ipari, nagyüzemi mezőgazdaságban a munkavállalói tulajdon megvalósítását, a munkahelyi demokrácia biztosítását és a munkavállalói jogok erősítését, valamint olyan kampányok indítását, amelyek alkalmasak az állam befolyásolására a humán és környezeti egészség előtérbe helyezésének érdekében.

Jelen müködését tekintve az élelmiszerrendszer tagjai a termelő és fogyasztó szerepekhez való ragaszkodással aktívan hozzájárulnak a hagyományos árutermelési és ellátási logika fenntartásához, és ezzel a mezőgazdaságban fennálló egyenlőtlen viszonyok megőrzéséhez (DeLind 2002). Levkoe (2006) szerint az élelmiszer-igazságosság egyik központi kihívása, hogy elmozdítsa az egyének élelmiszerhez való viszonyát a fogyasztói megközelítésből az állampolgári megközelítés felé. Ez megkövetelné a vevő- és eladószerepeken való túllépést, a közösségi szolidaritást és a rendszerkritikus megközelítést. Werkheiser és Noll (2014) az élelmiszer-igazságosság megvalósításának érdekében az egyéni célokat és érdekeket kereső mozgalmak helyett a közösségközpontú tevékenységek erősítését javasolja a globális élelmiszerrendszer átalakításához.

A közösségközpontú megközelítés Renting és munkatársai (2012) szerint az aktív civil szerepvállaláson keresztül érhető el, így javasolják a civil élelmiszer-hálózat rendszerének megvalósítását. Eszerint az élelmiszer-igazságossághoz vezető út fontos eleme az élelmiszer-önrendelkezés, ahol adott közösség tagjai (úgymint a közösség által támogatott mezőgazdaság esetében) kontrollal rendelkeznek az élelmiszer-termelés, -elosztás és -fogyasztás felett és ezzel új formáját tudják kialakítani a polgári/civil elköteleződésnek az élelmezéshez kapcsolódóan. Renting és munkatársai (2012) szerint a civil élelmiszer-hálózat alkalmas közeget teremthet az élelmiszer-igazságosság megvalósulásának, amennyiben ökológiai termelési módszereket használ, előtérbe helyezi a helyi és szezonális terményeket, és ezzel elkerüli a szükségtelen élelmiszer-kilométereket és energiafogyasztást. Nem mellesleg fair kompenzációt biztosíthat a termelőnek és az élelmiszerrendszerben dolgozó minden szereplőnek, valamint minden jövedelmi szintű tagnak egyenlő hozzáférési lehetőséget adhat a minőségi élelmiszerhez. Azonban ha egy alternatív élelmiszerrendszer nem tudja meghaladni a fogyasztói társadalom logikáját, ha a termelők elsősorban a vevői igények kielégítésére törekednek, és így próbálják felvenni a versenyt a többiekkel, akkor a múködésük csak annyiban lesz alternatív, hogy az élelmiszeripar hagyományos értékláncához képest más elosztási csatornát és kommunikációt használnak.

Úgy tûnik, hogy annak érdekében, hogy az élelmiszer-igazságosság megvalósulhasson, szükséges az államnak és a civil szférának az együttmúködése, valamint az 
is, hogy a fogyasztók a gazdasági cserén túlmenően értékalapú, etikai megfontolásokkal hozzanak döntéseket, vagyis legyen „a termékcserén túl a tranzakciókban meghatározó a morális tartalom" (Sage 2003: 50). Balázs (2020: 98) szerint az élelmiszerrendszer valódi változását mind termelői, mind fogyasztói oldalról „a földdel és a termelés feltételeivel való közvetlen kapcsolat jelentené”, tekintettel arra, hogy az élelmiszer különösen a közvetlen gazda-fogyasztó kapcsolatban értékes (Birtalan et al. 2021). Ennek elérése azonban kulturális és gazdasági változást igényelhet, amelyben minden fél elismeri, hogy az élelmiszer nem egyszerűen áru, hanem mindenkinek kijáró közjószág.

\section{Irodalom}

Alkon, A. H. (2014): Food Justice and the Challenge to Neoliberalism. Gastronomica, 14(2): 27-40. https://doi.org/10.1525/gfc.2014.14.2.27

Alkon, A. H. - Mares, T. M. (2012): Food sovereignty in US food movements: radical visions and neoliberal constraints. Agriculture and Human Values, 29(3): 347-359. https://doi.org/10.1007/s10460-012-9356-z

Allen, P. (2008): Mining for justice in the food system: perceptions, practices, and possibilities. Agriculture and Human Values, 25(2): 157-161.

https://doi.org/10.1007/s10460-008-9120-6

Allen, P. - FitzSimmons, M. - Goodman, M. - Warner, K. (2003): Shifting plates in the agrifood landscape: the tectonics of alternative agrifood initiatives in California. Journal of Rural Studies, 19(1): 61-75. https://doi.org/10.1016/S0743-0167(02)00047-5

Andersson, J. O. - Lindroth, M. (2001): Ecologically unsustainable trade. Ecological Economics, 37(1): 113-122. https://doi.org/10.1016/S0921-8009(00)00272-X

Balázs, B. (2020): Élelmiszer-önrendelkezés. Fordulat, 27, 82-101.

Balázs, B. - Pataki, G. - Lazányi, O. (2016): Prospects for the future: Community supported agriculture in Hungary. Futures, 83: 100-111.

Bársony F. (2020): Városi közösségi kertek Magyarországon. Tér és Társadalom, 34(1): 140-159.

Basok, T. - Ilcan, S. - Noonan, J. (2006): Citizenship, Human Rights, and Social Justice. Citizenship Studies, 10(3): 267-273.

https://doi.org/10.1080/13621020600772040

Báti, A. (2017): Organic Farm, Organic Food Steps Towards a Sustainable Agriculture (with Hungarian and Slovenian Examples). Acta Ethnographica Hungarica, 62(2): 269-275.

Beulens, A. J. M. - Broens, D.-F. - Folstar, P. - Hofstede, G. J. (2005): Food safety and transparency in food chains and networks Relationships and challenges. Food Control, 16(6): 481-486. https://doi.org/10.1016/j.foodcont.2003.10.010 
Birtalan, I. L. - Neulinger, Á. - Bárdos, G. - Rigó, A. - Rácz, J. - Boros, S. (2021): Local food communities: exploring health-related adaptivity and self-management practices. British Food Journal, 123(8): 2728-2742.

https://doi.org/10.1108/BFJ-12-2020-1176

Birtalan, I. L. - Bartha, A. - Neulinger, Á. - Bárdos, G. - Oláh, A. - Rácz, J. - Rigó, A. (2020): Community Supported Agriculture as a Driver of Food-Related WellBeing. Sustainability, 12(11): 4516. https://doi.org/10.3390/su12114516

Birtalan, I. L. - Kis, B. - Bárdos, Gy. - Rácz, J. - Oláh, A. - Rigó, A. (2019): Egészség a közösség által támogatott mezőgazdálkodásban, Alkalmazott Pszichológia, 19(3): 81-100.

Burt, K. G. - Mayer, G. - Paul, R. (2021): A systematic, mixed studies review of the outcomes of community garden participation related to food justice. Local Environment, 26(1): 17-42. https://doi.org/10.1080/13549839.2020.1861589

Cadieux, K. - Slocum, R. (2015): What does it mean to do food justice? Journal of Political Ecology, 22: 1-26. https://digitalcommons.hamline.edu/cla_faculty/3

Clendenning, J. - Dressler, W. H. - Richards, C. (2016): Understanding the rise of urban food movements in the USA. Agriculture and Human Values, 33(1): 165-177.

Czagány, L. (2009): Az élelmiszer-önrendelkezés koncepciója és magyarországi realitásai. Jelenkori Társadalmi és Gazdasági Folyamatok, 4(1): 23-28.

DeLind, L. B. (2002): Place, work, and civic agriculture: Common fields for cultivation. Agriculture and Human Values, 19(3): 217-224.

https://doi.org/10.1023/A:1019994728252

Dixon, B. A. (2014): Learning to see food justice. Agriculture and Human Values, 31(2): 175-184. https://doi.org/10.1007/s10460-013-9465-3

DuPuis, M. - Goodman, D. (2005): Should we go home to eat? Toward a reflexive politics of localism. Journal of Rural Studies, 21(3): 359-371.

https://doi.org/10.1016/j.jrurstud.2005.05.011

DuPuis, E. M. - Harrison, J. L. - Goodman, D. (2011): Just food. In Alkon, A. H. Agyeman, J. (szerk.): Cultivating food justice: Race, class, and sustainability. Cambridge: MIT Press, 283-307.

Éber, M. Á. - Gagyi, Á. - Gerőcs, T. - Jelinek, C. (2019): 2008-2018: Válság és hegemónia Magyarországon. Fordulat, 26(2): 28-75.

Edwards-Jones, G. - Milà i Canals, L. - Hounsome, N. - Truninger, M. - Koerber, G. - Hounsome, B. - Cross, P. - York, E. H. - Hospido, A. - Plassmann, K. - Harris, I. M. - Edwards, R. T. - Day, G. A.S. - Tomos, A. D. - Cowell, S. J. - Jones, D. L. (2008): Testing the assertion that 'local food is best': the challenges of an evidence-based approach. Trends in Food Science \& Technology, 19(5): 265-274. https://doi.org/10.1016/j.tifs.2008.01.008

Evans, N. - Morris, C. - Winter, M. (2002). Conceptualizing agriculture: a critique of post-productivism as the new orthodoxy. Progress in Human Geography, 26(3): 313-332. 
Farkas, J. (2014): „Kicsi kis hősök” - Az ökofalu-mozgalom története és gyökerei. Kovász, 1-4: 43-66.

Feagan, R. B. - Morris, D. (2009): Consumer quest for embeddedness: a case study of the Brantford Farmers' Market. International Journal of Consumer Studies, 33(3): 235-243. https://doi.org/10.1111/j.1470-6431.2009.00745.x

Feenstra, G. (1997): Local Food Systems and Sustainable Communities. American Journal of Alternative Agriculture, 12: 28-36. https://doi.org/10.1191/0309132502ph372ra

Forno, F. - Graziano, P. R. (2014): Sustainable community movement organisations. Journal of Consumer Culture, 14(2): 139-157.

https://doi.org/10.1177/1469540514526225

Fournier, B. - Kushner, K. - Raine, K. (2019): 'To me, policy is government': Creating a locally driven healthy food environment in the Canadian Arctic. Health \& Place, 58: 102138. https://doi.org/10.1016/j.healthplace.2019.05.016

Galt, R. E. (2013): The Moral Economy Is a Double-edged Sword: Explaining Farmers' Earnings and Self-exploitation in Community-Supported Agriculture: The Moral Economy Is a Double-edged Sword. Economic Geography, 89(4): 341-365.

DOI: 10.1111/ecge.12015

Gottlieb, R. - Joshi, A. (2010): Food Justice. Cambridge: The MIT Press. Letöltés helye: https://mitpress.mit.edu/books/food-justice

Grasseni, C. - Paxson, H. - Bingen, J. - Cohen, A. J. - Freidberg, S. - West, H. G. (2014): Introducing a Special Issue on the Reinvention of Food Connections and Mediation. Gastronomica, 14(4): 1-6. https://doi.org/10.1525/gfc.2014.14.4.1

Guthman, J. (2008): Bringing good food to others: investigating the subjects of alternative food practice. Cultural Geographies, 15(4): 431-447. https://doi. org/10.1177/1474474008094315

Harcsa I. (2016): A föld és társadalma. Alul és felül a történelem sodrásában. Gondolatok Kovách Imre: „Földek és emberek” című műve kapcsán. Metszetek, 2: 127-137.

Harcsa, I. - Kovách, I. - Szelényi, I. (1994): A posztszocialista átalakulási válság a mezőgazdaságban és a falusi társadalomban. Szociológiai Szemle, 3: 15-43.

Holt-Giménez, E. (2010): Food Security, Food Justice, or Food Sovereignty? Food First Backgrounder, 16(4): 1-4.

Holt-Giménez, E. - Wang, Y. (2011): Reform or transformation? The pivotal role of food justice in the US food movement. Race/Ethnicity: Multidisciplinary Global Contexts, 5(1): 83-102. https://doi.org/10.2979/racethmulglocon.5.1.83

Jarosz, L. (2008): The city in the country: Growing alternative food networks in Metropolitan areas. Journal of Rural Studies, 24(3): 231-244.

https://doi.org/10.1016/j.jrurstud.2007.10.002 
Karr, J. R. (1996): Ecological Integrity and Ecological Health Are Not the Same: Engineering within Ecological Constraints. In Schulze, P. (szerk.): Engineering Within Ecological Constraints. Washington: National Academy Press, 97-110.

Kingsley, J. „Yotti” - Townsend, M. - Henderson-Wilson, C. (2009): Cultivating health and wellbeing: members' perceptions of the health benefits of a Port Melbourne community garden. Leisure Studies, 28(2): 207-219.

https://doi.org/10.1080/02614360902769894

Kneafsey, M. - Venn, L. - Schmutz, U. - Balázs, B. - Trenchard, L. - Eyden- Wood, T. - Bos, E. - Sutton, G. - Blackett, M. (2013): Short food supply chains and local food systems in the EU. A state of play of their socio-economic characteristics. JRC Scientific and Policy Reports. Luxembourg: Joint Research Centre Institute for Prospective Technological Studies, European Commission.

Kovács, K. (2016): Földből élők. Polarizáció a magyar vidéken. Budapest: Argumentum Kiadó.

Lányi A. (2010): A környezetbarát gazdálkodás és a közösségi vállalkozás esélyei egy aprófalvas régióban. Szociológiai Szemle, 21(2): 94-131.

Levkoe, C. Z. (2006): Learning Democracy Through Food Justice Movements. Agriculture and Human Values, 23(1): 89-98.

https://doi.org/10.1007/s10460-005-5871-5

Levkoe, C. Z. (2018): Engaging the tensions of ecological internships: Considerations for agroecology and sustainable food systems movements. Agroecology and Sustainable Food Systems, 42(3): 242-263.

https://doi.org/10.1080/21683565.2017.1347120

Lockie, S. (2009): Responsibility and agency within alternative food networks: assembling the 'citizen consumer'. Agriculture and Human Values, 26(3): 193-201. https://doi.org/10.1007/s10460-008-9155-8

Lyson, T. A. (2004): Civic Agriculture: Reconnecting Farm, Food, and Community, Medford, Mass. - Lebanon, NH: University Press of New England.

Málovics, G. (2012): Környezetvédelem vagy társadalmi igazságosság? A környezeti igazságosság koncepciójának értelmezési lehetőségei és hazai jelentősége. Kovász, 16(1-4): 3-31.

Martin, P. - Consalès, J.-N. - Scheromm, P. - Marchand, P. - Ghestem, F. - Darmon, N. (2017): Community gardening in poor neighborhoods in France: A way to rethink food practices? Appetite, 116: 589-598.

https://doi.org/10.1016/j.appet.2017.05.023

McMichael, P. (2019): A parasztok maguk csinálják történelmüket, de nem szabadon. Fordulat, 25: 159-191.

Meenar, M. - Hoover, B. (2012): Community Food Security Via Urban Agriculture: Understanding People, Place, Economy, and Accessibility from A Food Justice Perspective. Sociology Educator Scholarship. Letöltés helye:

https://mosaic.messiah.edu/soc_ed/27 
Minkoff-Zern, L.-A. (2017): Farmworker-led food movements then and now. The New Food Activism: Opposition, Cooperation, and Collective Action. In Alkon, A. H. - Guthman, J. (szerk.): The New Food Activism. California: Univ. of California Press, 157-178.

Mount, P. (2012): Growing local food: scale and local food systems governance. Agriculture and Human Values, 29(1): 107-121.

https://doi.org/10.1007/s10460-011-9331-0

MTVSZ (2015): Agroökológia - egy új élelmezési rendszer Európa számára. Letöltés helye: https://mtvsz.hu/dynamic/agrookologia_kiadvany.pdf.

Neulinger, Á. - Bársony, F. - Gjorevska, N. - Lazányi, O. - Pataki, G. - Takács, S. - Török, A. (2020a): Engagement and subjective well-being in alternative food networks: The case of Hungary. International Journal of Consumer Studies, 44(4): 306-315. https://doi.org/10.1111/ijcs.12566

Neulinger, Á. - Bársony, F. - Lazányi, O. (2020b): „Hasonló értékrendű emberek vagyunk": Az ételválasztás és az étkezés értékkifejező szerepe, különös tekintettel az alternatív élelmiszerbeszerzési helyzetekre. Jel-Kép, 4: 57-77.

https://DOI:10.20520/JEL-KEP.2020.4.57

Obach, B. K. - Tobin, K. (2014): Civic agriculture and community engagement. Agriculture and Human Values, 31(2): 307-322. https://doi.org/10.1007/s10460013-9477-z

OECD (2011): How's Life?: Measuring Well-Being. OECD. Letöltés helye: https://doi.org/10.1787/9789264121164-en

Örkény, A. - Székelyi M. (1999): Igazságosság és társadalomkép. Századvég, tél: 87-113.

Örkény, A. - Székelyi, Mm (2010): Az igazságosság labirintusaiban: A társadalmi igazságosság normatív elveitől az igazságos elosztás gyakorlatáig. Szociológia Szemle, 20(2): 4-41.

Perry, J. A. (2019): Images of work, images of defiance: engaging migrant farm worker voice through community-based arts. Agriculture and Human Values, 36(3): 627-640. https://doi.org/10.1007/s10460-018-9861-9

Power, E. M. (1999): Combining social justice and sustainability for food security. In M. Koc, R. - MacRae, R. - Mougeot, L. J. A. - Welsh, J. (szerk.): For hunger-proof cities: Sustainable urban food systems. Ottawa: International Development Research Centre, 30-37.

Reich, B. J. - Beck, J. T. - Price, J. (2018): Food as Ideology: Measurement and Validation of Locavorism. Journal of Consumer Research, 45(4): 849-868. https://doi.org/10.1093/jcr/ucy027

Renting, H. - Marsden, T. K. - Banks, J. (2003): Understanding Alternative Food Networks: Exploring the Role of Short Food Supply Chains in Rural Development. Environment and Planning A: Economy and Space, 35(3): 393-411. https://doi.org/10.1068/a3510 
Renting, H. - Schermer, M. - Rossi, A. (2012): Building Food Democracy: Exploring Civic Food Networks and Newly Emerging Forms of Food Citizenship. The International Journal of Sociology of Agriculture and Food, 19(3): 289-307.

https://doi.org/10.48416/ijsaf.v19i3.206

Renting, H. - Van Der Ploeg, J. D. (2001): Reconnecting nature, farming and society: environmental cooperatives in the Netherlands as institutional arrangements for creating coherence. Journal of Environmental Policy \& Planning, 3(2): 85-101. https://doi.org/10.1002/jepp.75

Rothwell, A. - Ridoutt, B. - Page, G. - Bellotti, W. (2016): Environmental performance of local food: trade-offs and implications for climate resilience in a developed city. Journal of Cleaner Production, 114: 420-430.

https://doi.org/10.1016/j.jclepro.2015.04.096

Sachs, C. - Allen, P. - Terman, A. R. - Hayden, J. - Hatcher, C. (2014): Front and back of the house: socio-spatial inequalities in food work. Agriculture and Human Values, 31(1): 3-17. https://doi.org/10.1007/s10460-013-9445-7

Sage, C. (2003): Social embeddedness and relations of regard: alternative 'good food' networks in south-west Ireland. Journal of Rural Studies, 19(1): 47-60.

https://doi.org/10.1016/S0743-0167(02)00044-X

Sbicca, J. (2012): Growing food justice by planting an anti-oppression foundation: opportunities and obstacles for a budding social movement. Agriculture and $\mathrm{Hu}$ man Values, 29(4): 455-466. https://doi.org/10.1007/s10460-012-9363-0

Sharman, T. (2007): The Evolution of British Trade Justice Campaigning. Review of African Political Economy, 34(112): 385-392.

Szente, V. - Fertő, I. - Benedek, Z. (2021): Hozzájárul-e a helyi élelmiszer vásárlás a helyi gazdaság fejlődéséhez? Egy szisztematikus irodalmi áttekintés. Tér és Társadalom, 35: 49-68. https://doi.org/10.17649/TET.35.2021.3321

Török, A. - Neulinger, Á. - Pataki, G. - Bársony, F. - Lazányi, O. (2020): Quality. Local. Social. What else? Which factors motivate consumers to participate in alternative food networks in Hungary? Revista Iberoamericana de Economía Solidaria e Innovación Socioecológica, 3: 169-187.

Totth, G. - Kovács, I. - Oravecz, T. É. M. - Mucha, L. (2019): A védjegyek szerepe, és fogyasztói megítélése. Jelenkori Társadalmi és Gazdasági Folyamatok, 14(2): 215-236.

Touraine, A. (1985): An Introduction to the Study of Social Movements. Social Research, 52(4): 749-787.

Turner, N. J. - Turner, K. L. (2008): 'Where our women used to get the food': cumulative effects and loss of ethnobotanical knowledge and practice. Botany, 86(2): 103-115.

Venn, L. - Kneafsey, M. - Holloway, L. - Cox, R. - Dowler, E. - Tuomainen, H. (2006): Researching European 'alternative' food networks: some methodological considerations. Area, 38(3): 248-258.

https://doi.org/10.1111/j.1475-4762.2006.00694.x 
Vitiello, D. - Grisso, J. A. - Whiteside, K. L. - Fischman, R. (2015): From commodity surplus to food justice: food banks and local agriculture in the United States. Agriculture and Human Values, 32(3): 419-430.

https://doi.org/10.1007/s10460-014-9563-x

Watts, D. C. H. - Ilbery, B. - Maye, D. (2005). Making reconnections in agro-food geography: alternative systems of food provision. Progress in Human Geography, 29(1): 22-40. https://doi.org/10.1191/0309132505ph526oa

Wekerle, G. R. (2004): Food Justice Movements: Policy, Planning, and Networks. Journal of Planning Education and Research, 23(4): 378-386.

https://doi.org/10.1177/0739456X04264886

Welsh, J. - MacRae, R. (1998): Food Citizenship and Community Food Security: Lessons from Toronto, Canada. Canadian Journal of Development Studies/Revue Canadienne d'études Du Développement, 19(4): 237-255.

https://doi.org/10.1080/02255189.1998.9669786

Werkheiser, I. - Noll, S. (2014): From Food Justice to a Tool of the Status Quo: Three Sub-movements Within Local Food. Journal of Agricultural and Environmental Ethics, 27(2): 201-210. https://doi.org/10.1007/s10806-013-9459-6

Wheeler, K. (2012): Fair Trade and the Citizen-Consumer: Shopping for Justice? New York: Palgrave Macmillan.

Yale, L. - Venkatesh, A. (1986): Toward the Construct of Convenience in Consumer Research. ACR North American Advances, 13. Letöltés helye:

https://www.acrwebsite.org/volumes/5956/volumes/v13/NA-13/full

Zoll, F. - Specht, K. - Opitz, I. - Siebert, R. - Piorr, A. - Zasada, I. (2018): Individual choice or collective action? Exploring consumer motives for participating in alternative food networks. International Journal of Consumer Studies, 42(1): 101-110. https://doi.org/10.1111/ijcs.12405

\section{Hivatkozott honlapok}

ESSRG [é. n.]: https://www.essrg.hu/hu/, letöltve: 2021. 08. 01.

Food Not Bombs [é. n.]: https://foodnotbombs.net/new_site/, letöltve: 2021. 08. 01. Kislépték [é. n.]: https://kisleptek.hu, letöltve: 2021. 08. 01.

Közgazdaság- és Regionális Tudományi Kutatóközpont [é. n.]:

https://www.krtk.hu, letöltve: 2021. 08. 01.

Magház [é. n.]: https://www.maghaz.hu, letöltve: 2021. 08. 01.

Magyar Permakultúra Egyesület [é. n.]: https://permakultura.hu, letöltve: 2021. 08. 01.

Szolidáris Gazdaság Központ [é. n.]: https://szolidarisgazdasagkozpont.hu, letöltve: 2021. 08. 01.

Tudatos Vásárlók Egyesülete [é. n.]: https://tudatosvasarlo.hu, letöltve: 2021. 08. 01.

Védegylet [é. n.]: www.vedegylet.hu, letöltve: 2021. 08. 01. 